\title{
Negotiating, Constructing and Reconstructing Girlhoods
}

\author{
Fiona Leach
}

\section{$\cos 80$}

I am honoured to have been invited to write an introduction for this special issue of Girlhood Studies commemorating the life and work of Jackie Kirk. I first met Jackie at a conference in Washington in 1998. She subsequently spent several weeks at Sussex University in 2001 working on her doctorate on women teachers in development contexts. Later she contributed to several edited collections I was involved in. Her determination to work for the improvement of girls' education in those parts of the world where access is frequently denied and where women's lives are particularly difficult was very apparent. This belief in the possibility of change in the most desperate of circumstances and the importance of education in helping women and girls rebuild their lives in conflict-torn countries was to cost Jackie her life in Afghanistan in August 2008. She was that rare individual — an activist and advocate as well as an academic and researcher-committed equally to the pursuit of knowledge and to action for change. Jackie believed that we can and should make a difference.

Jackie also contributed to the inspiration behind the launch of Girlhood Studies. I hope that this special issue of the journal, which aptly reflects numerous facets of her work, provides a fitting, albeit small, tribute to a courageous and talented person. By bringing together a number of articles which capture the voices and experiences of girls and young women, it seeks to extend our understanding of how they negotiate, construct and reconstruct girlhood in challenging situations, whether these be as a consequence of war, violence, globalization, HIV and AIDS, or economic and social deprivation. This is what Jackie would have wanted.

The issue ends with a special Celebration and Remembrance section made up of a series of short pieces, including a poem written for Jackie by Montreal poet, Charlotte Hussey, a tribute submitted by Lyndsay Bird of the International Institute for Educational Planning (IIEP, Paris) one of many global organizations with whom Jackie worked, two 
short essays written by young researchers, Stephen Peters and Zainul Sajan Virgi, working in the area of girlhood at McGill University where Jackie completed her own PhD. and an announcement by Taffeta Productions that the proceeds of Jackie's video Women Educating for Peace will be donated to a non-profit education media organization in Quebec, Canada.

This issue celebrates her life and work on several levels. Several contributions address the impact of conflict on girlhood experiences in countries which have recently experienced civil war, including three where Jackie worked (Sierra Leone, Ethiopia and Lebanon). Others address issues that Jackie was equally passionate about-alleviating the impact of external forces such as globalization, economic decline and changing family structures on girlhood experiences, and highlighting the importance of education in helping girls make a safe transition to womanhood.

The special issue starts with an essay by Cathryn Magno and Jackie Kirk based on work that they were carrying out at the time of Jackie's death in August 2008. Cathryn finalized the essay using a co-authored report to UNICEF. As she tells us, a draft of the article "Sight Unseen: Re-viewing Images of Girls' Education” was co-written just before Jackie's death. She goes on to point out that "much of the original phrasing and diction have been retained in order to preserve [Jackie's] customary sharp thinking, keen insights, and poignant expression". She is sure that "Jackie would be very pleased to see this article in print, as she would be of all the articles in this very special issue of Girlhood Studies."

This is followed by Kathleen Fincham's article which explores how Palestinian girls, affected by conflict in unique ways, construct girlhood within the very constrained space of the refugee camp, where they must negotiate the difficult terrain of the male-dominated "nationalist project" and are expected to subordinate personal aspirations to the "greater cause" of nationhood. Two articles which examine girlhood in postconflict Sierra Leone follow. Donna Sharkey assesses the continuing risks of violence to schoolgirls even after the fighting has stopped, while Alastair Ager, Lindsay Stark, Joanna Olsen, Mike Wessells and Neil Boothby examine strategies to support the reintegration of girls abducted by armed groups into their communities. A global examination of the changing roles of girls and young women "in the shadow of war" by Nikki Van der Gaag, Sarah Hendriks and Feyi Rodway is next. 
The special issue then moves to a broader canvas in its addressing of the shifting nature of girlhood in a rapidly globalizing world characterised by other kinds of pressures. Marni Sommer examines the inter-generational tensions between family expectations and girls' personal aspirations in two communities in Tanzania, between "the simultaneous pull-back tug of tradition, and the pull-forward draw of modernization and its (perceived) freedoms". She shows how experiences of girlhood and the transition to womanhood are changing for young women as extended family structures shift because of globalization, economic migration and the impact of HIV and AIDS, and how access to the global imagery of girlhood increases the speed of change and the size of the generation gap, even in rural communities. Heather Switzer then looks at how Maasai girlhood narratives in Kenya have constructed a new social category of "schoolgirl" in opposition to the "girl-child" much favoured in recent years by mainstream development discourse but reduced to essentialized voiceless victim. For these girls, by contrast, the category "schoolgirl" embodies freedom, status and agency, and they articulate a firm belief that education offers them the only possible route to success in their world. Finally a report by Hirut Tefferi, Katy Anis and Bilen Tenna looks at how girls at risk of sexual abuse and exploitation in Ethiopia develop the necessary resilience to persist with their schooling against the odds.

The contributions to this special issue share certain striking features which resonate with Jackie's work and illuminate the nature of her commitment. Most noticeable is the positioning of girls on the margins of community and society, as peripheral to decision-making, as simultaneously ignored and exploited. Evidence suggests that where there exists a strong patriarchal imperative and a highly gendered division of labour, girls are more likely to suffer from a range of abusive behaviours, whether in the home, the community or the school. And where police and judicial procedures are weak (and often corrupt), girls are more likely to be exposed to violence and very unlikely to obtain redress. In such settings, the route to acquiring status for girls is well defined and narrow: it is gained through marriage and child-bearing. One consequence of this lack of power and status is to deprive girls and young women of a voice in decisions that affect their own lives, even on programs being designed to protect and support girls themselves. 
At the same time, the evidence on which the articles draw firmly repudiates the notion of girls as victims. Within the narrow spaces accorded them, girls can and do exercise agency and resist the constraints and silences that society tries to impose on them. The articles give girls a voice and place them centre stage, just as Jackie sought to do through her work, in the conviction that in settings characterised by violence, conflict and rapid globalization, this is the most effective way of helping to improve young women's lives. By listening to their experiences and understandings of girlhood, appropriate strategies of support can be developed.

Alongside the challenging conditions outlined above, there is therefore room for optimism. The articles show that out of adversity can come the potential for positive change to girls' lives, and that girls themselves can develop the necessary determination and capabilities to develop responses and strategies to protect themselves and manage hostile environments. For example, Nikki Van der Gaag and her co-authors show that, as girls and young women face traumatic changes to their lives during civil or military conflict and experience the weakening of institutions of family, community and government, they may be required to adopt unfamiliar roles and develop coping mechanisms. These, however, may generate new strengths, new freedoms and enhanced status. The authors argue that, instead of requiring girls to give up these more public and visible roles once the fighting stops and return to the obscurity of the home, the opportunity should be grasped to shape these new capabilities into tools for girls' empowerment and involve girls and young women in policy decisions around responses to violence and peace-building initiatives.

Likewise, the girls in Marni Sommer's study in Tanzania, despite expressing anxiety about the influence of globalization and the greater freedoms suggested by Western-dominated global images, appreciated the new ideas and changes offered by access to global information. Unlike their parents who tended to see this as a negative influence, they understood the new opportunities that globalization can provide, for possible careers, professional pursuits, improved lifestyles and material possessions. Sommer argues that a better understanding of how globalizing influences and imagery are changing girls' experiences of girlhood, from the perspectives of girls themselves and the adults who 
interact with them, will make it easier to develop effective forms of support and guidance as they journey into adulthood.

Even amidst the despondency and the constrained space (physical and intellectual) of the long-term refugee camp, Palestinian girls were able to envisage a better future and fashion their own aspirational narratives of girlhood from the conflicting discourses of gender and nation. From the limited gender scripts available to them, they exercised a degree of agency by forming new hybrid gender identities based on versions of Islamic feminism (an antithesis to Western feminist notions of emancipation) and secularism (for example, by combining Western clothes with the hijab as the embodiment of resistance to Western hegemony).

One particularly uplifting and striking theme that weaves through the contributions is that of girls' resilience and resourcefulness in the face of adversity. However stark the reality of their daily lives, the girls' narratives of survival and aspiration against the odds offer hope. This resilience can be tapped into to improve girls' lives as well as those of their communities. As Hirut Tefferi, Katy Anis and Bilen Tenna point out in their Ethiopian report, acknowledging and understanding young people's inherent strengths and their remarkable ability to recover from situations of extreme stress can inform strategies for working with disadvantaged populations, in particular through giving greater focus to, and building on, areas of strength.

Much of Jackie's work was within the education sector, building on the potential of education to improve the lives of children and young people living with conflict, the aftermath of conflict, or with poverty and deprivation. All the girls who feature in these articles value education: they believe in the enhanced status of the schoolgirl and see schooling as offering important benefits such as delayed marriage and more life choices. They all want to persist despite the many challenges. Donna Sharkey found that girls in Sierra Leone, despite the daily risk of being beaten and insulted by teachers and bullied by fellow students, appreciate their education-as a means of escaping from ill-treatment in the home and delaying early marriage and pregnancy, as an opportunity for socialising and friendship denied them elsewhere, and for the enhanced status it brings them, and the potential to transform their lives socially and economically. To the Maasai girls in Heather Switzer's 
research and the Palestinian girls in Kathleen Fincham's, remaining in school is also an act of agency and resistance to conventional gendered expectations.

It is widely acknowledged that education can provide young people with important knowledge and skills to navigate an unfamiliar and rapidly changing world and that it can challenge entrenched gender roles, and promote gender equality and empowerment for girls. Yet, we need to heed Switzer's words of caution that, in contexts which are "hostile to the transformations that education can bring about", the neo-liberal discourse around education as a neutral public good and a means out of poverty has been undermined and its "emancipatory potential" (and that of the schoolgirl construct) largely lost in the face of the realities of economic decline and marginalization. Listening to girls' experiences, hopes and desires may help us to render education more relevant and empowering — something that Jackie was committed to throughout her professional work. 